\title{
Vegetation dynamics and their response to freshwater inflow and climate variables in the Yellow River Delta, China
}

\author{
Dejuan Jiang $^{\mathrm{a}, *}$, Xinfeng Fu ${ }^{\mathrm{b}}$, Kun Wang ${ }^{\mathrm{c}}$ \\ ${ }^{a}$ Key Laboratory of Coastal Zone Environmental Processes, Yantai Institute of Coastal Zone Research (YIC), Chinese Academy of Sciences (CAS), \\ Shandong Provincial Key Laboratory of Coastal Zone Environmental Processes, YICCAS, Laishan District, Chunhui Road 17, \\ Yantai, Shandong 264003, PR China \\ ${ }^{\mathrm{b}}$ Yellow River Institute of Hydraulic Research, Zhengzhou 450003, China \\ ' State Key Laboratory of Remote Sensing Science, Jointly Sponsored by the Institute of Remote Sensing Applications of Chinese Academy of Sciences \\ and Beijing Normal University, Beijing 100101, China
}

\section{A R T I C L E I N F O}

Article history:

Available online 5 November 2012

\begin{abstract}
A B S T R A C T
Based on SPOT Vegetation NDVI data, streamflow data and meteorological data, the variation of vegetation cover, measured by the Normalized Difference Vegetation Index (NDVI), and its response to freshwater inflow, precipitation and temperature in the Yellow River Delta and its buffer zones have been investigated for the period 1998-2009. The results show that NDVI has a remarkable regional and seasonal difference. The farther from the Yellow River Channel and the nearer to the Bohai Sea Coastline, the smaller the NDVI value, as influenced by the interaction between freshwater and saltwater on vegetation. Seasonally, high NDVI values appear in summer (August) and low in spring (April). From 1998 to 2009, growing season NDVI significantly increases in the Yellow River Delta. Summer and autumn NDVI have a similar trend pattern to growing season NDVI, while spring NDVI significantly decreases. NDVI shows different strengths of correlation with freshwater inflow, precipitation and temperature respectively and these correlations vary in different seasons and months. Freshwater inflow is a key factor for vegetation dynamics and NDVI variation. Climate features play a dominant role in seasonal variation in vegetation cover. However, the impacts of freshwater inflow and climate variables on vegetation have been greatly modified by a range of human activities such as land use pattern and land use change as well as water diversion from the Yellow River. Overall, the results of this study can be helpful for decision-making of regional ecological protection and economic development.
\end{abstract}

(c) 2012 Elsevier Ltd and INQUA. All rights reserved.

\section{Introduction}

Vegetation is an important part of terrestrial ecosystems and is a natural intermediate link in pedosphere, atmosphere and hydrosphere of the earth's system (Salim et al., 2008; Zhong et al., 2010), which serves as a sensitive indicator for the status of ecosystems as well as global and local environment changes (Piao et al., 2006; Yu et al., 2006; Potter et al., 2008; Salim et al., 2008). Vegetation characteristics are closely associated with their environmental conditions, such as climate features, water conditions, and topography (Piao et al., 2006; Fabricante et al., 2009; Meng et al., 2011). Presently, research has been conducted to examine the correlations between vegetation cover and climate variables (mostly focusing on precipitation and temperature) at regional or

\footnotetext{
* Corresponding author.

E-mail address: djjiang@yic.ac.cn (D. Jiang).
}

national scales (Nemani et al., 2003; Roerink et al., 2003; Piao et al., 2006; Notaro, 2008; Fabricante et al., 2009; Wu et al., 2009; Zhong et al., 2010; Meng et al., 2011). Exploring vegetation dynamics and their response to climate variables has become one of the main themes of global change studies (Rees et al., 2001; Yu et al., 2006).

In estuarine areas, plant species and communities are influenced by not only climate variables but also water table depth, salinity gradient, and flow conditions. Freshwater inflow is vital to the creation and maintenance of estuarine habitats. The amount, duration and fluctuation of freshwater inflow, interacting with tides and coastal dynamics, greatly affect vegetation dynamics (Xu and Wu, 2006; Hyfield et al., 2008; Wu et al., 2009; Cui et al., 2010). Moreover, many materials such as sediment and nutrients carried by streamflow from upstream areas are also important factors for plant growth.

The Yellow River Delta (YRD) is one of the most active regions of land-ocean interaction among the large river deltas in the world (Li et al., 2009; Cui et al., 2009a). In recent years, jointly influenced 
by global climate change and human activities, water of the Yellow River discharged into the Bohai Sea has been greatly reduced, and the frequency of complete drying or ephemeral flow of the downstream river channel has increased (Xie et al., 2010). Meanwhile, the YRD also has been undergoing extensive and rapid development of industry and agriculture as well as oil exploitation and road construction (Wang et al., 2011; Zhang et al., 2011). These facts result in serious degradation to the YRD wetland ecosystem and greatly threaten plant species and communities. Fortunately, since 2002, water and sedimentation regulation in the Yellow River has been implemented by the Yellow River Conservancy Commission (YRCC). Hence, the streamflow of the downstream river channel has greatly increased from 2003, which has made it possible to provide sufficient water for habitat restoration (Cui et al., 2009b).

However, this regulation only occurs in summer and lasts for appropriately 20 days. Therefore, it is difficult to ensure adequate water supply for the YRD estuarine habitats throughout the year, especially in the low flow season. At present, one of the major challenges for water resource management is to assess how much water needs to be allocated and how to optimize water allocation for the protection and restoration of estuarine wetland ecosystem. Some studies have documented environmental flows for wetlands or the effects of water table depth and soil salinity on vegetation (e.g. Sun et al., 2008, 2012; Cui et al., 2009a, 2010; An et al., 2011; Wang et al., 2011), but little effort has been made to investigate vegetation response to freshwater inflow.

This research aims to investigate the variation in vegetation cover and its response to freshwater inflow as well as precipitation and temperature in the YRD based on remote sensing data, streamflow data and meteorological data for the period 19982009. This study will be helpful for decision-making regarding water resources utilization and is expected to provide an information base for the protection and restoration of estuarine wetland ecosystem. Because, in the YRD, most natural plants are deciduous or wilted and agricultural lands are almost clear in winter, this study only focuses on the analysis of the growing season (from April to November). Then, growing season is further classified into three seasons as spring (April-May), summer (June-August) and autumn (September-November).

\section{Data and methods}

\subsection{Study area}

The YRD is situated in the northeast part of Shandong province, China, and on the southwest coast of the Bohai Sea $\left(37^{\circ} 16^{\prime} \mathrm{N}-\right.$ $38^{\circ} 09^{\prime} \mathrm{N}$; $118^{\circ} 06^{\prime} \mathrm{E}-119^{\circ} 45^{\prime} \mathrm{E}$ ) with an area of $6113 \mathrm{~km}^{2}$ (Fig. 1). This area is characterized by the warm temperate continental monsoon climate with distinctive seasons. The annual mean air temperature is $12.1^{\circ} \mathrm{C}$ with 196 frostless days. The annual average precipitation and evaporation are approximately $576.7 \mathrm{~mm}$ and $1962 \mathrm{~mm}$ respectively, with about $70 \%$ of the annual total precipitation falling in summer. There is no zonal vegetation. Natural vegetation includes Phragmites australis, Suaeda heteroptera, Tamarix chinensis, Triarrhena sacchariflora, Myriophyllum spicatum, Limonium sinense. Crop plants are corn, winter wheat, soybean, cotton and rice. Alluvial soil and saline soil are the dominant soil types.

The YRD is the fastest growing delta in the world. Large amounts of sediment are carried by the Yellow River and deposited in the delta, forming a vast area of floodplain and special estuarine wetland landscape (Xu et al., 2002; Fang et al., 2005; Cui et al., 2009b). The YRD wetland (Fig. 1) is one of the international important wetlands and is one of the important habitats for many rare and endangered migrating birds, such as Red-crowned Crane, Hooded Crane, Siberian Crane, Oriental stork, Black stork, and Golden Eagle, in the world and has enormous economic potential for sustainable development (Sun et al., 2008; Cui et al., 2010). It also performs vast ecological functions, including water purification, coastal protection, groundwater recharge, flood regulation, and climatic regulation (Xie et al., 2010; Wang et al., 2011).
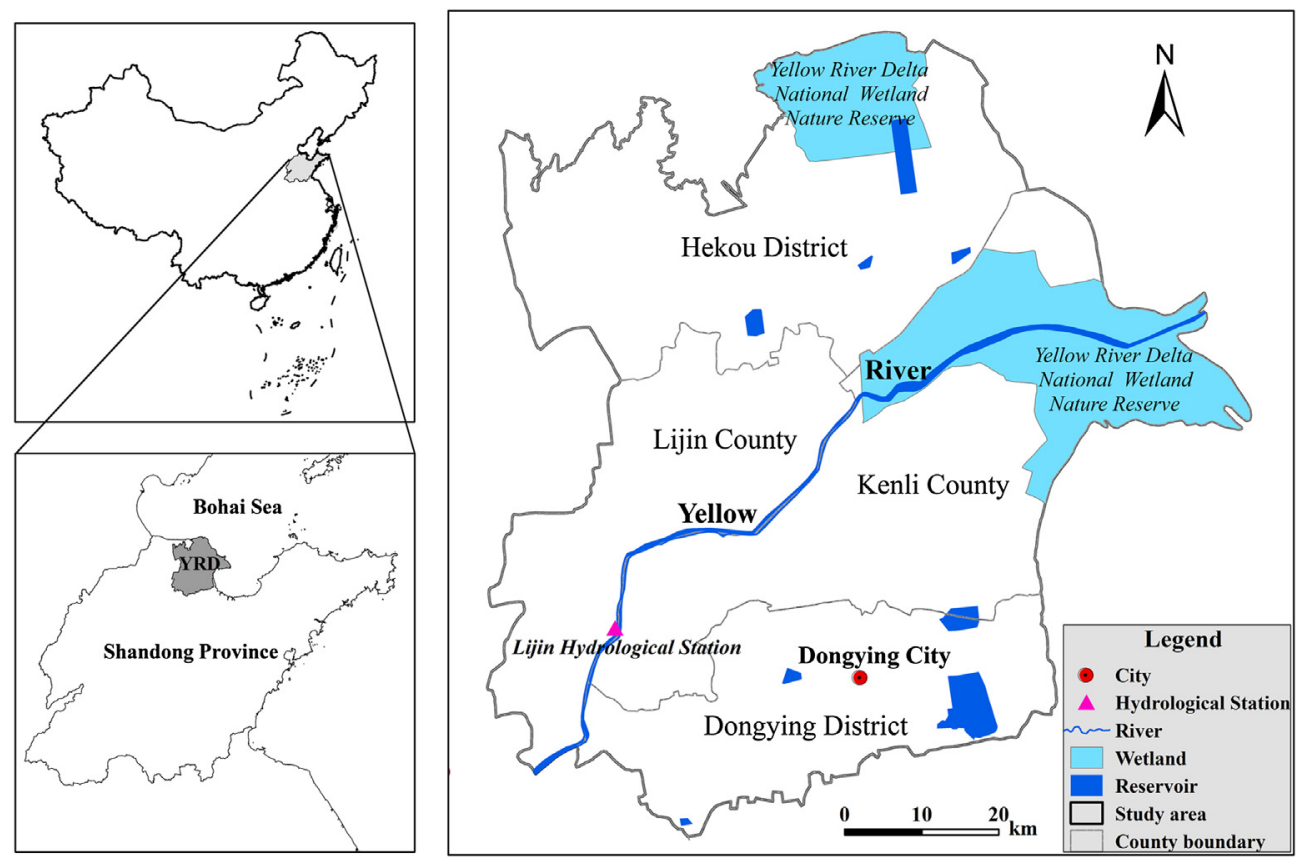

Fig. 1. Map of the Yellow River Delta (YRD). 


\subsection{Data and methods}

Remote sensing provides an effective tool to monitor and quantify vegetation cover of a terrestrial ecosystem (Roerink et al., 2003; Salim et al., 2008; Zhong et al., 2010). Among various remotely-sensed vegetation indices, the Normalized Difference Vegetation Index (NDVI) is regarded as a good indicator for vegetation parameters such as vegetation coverage, leaf area index, photosynthesis and net primary productivity, which has been widely used to explore vegetation dynamics and their relationships with environmental factors (e.g., Roerink et al., 2003; Piao et al., 2006; Salim et al., 2008; Wu et al., 2009; Zhong et al., 2010; An et al., 2011; Meng et al., 2011). In this study, the SPOT Vegetation NDVI data with a spatial resolution of $1 \mathrm{~km}^{2}$ and a 10day interval, which are acquired from the website of http://free. vgt.vito.be for the period April 1998 to November 2009, are used for the analysis of vegetation dynamics and their response to freshwater inflow and climate variables. The monthly NDVI values are generated using the maximum value composing (MVC) method in an effort to minimize atmospheric effects, scan angle effects, cloud contamination and solar zenith angle effects (Holben, 1986; Piao et al., 2004). In the same way, NDVI values during growing season and three seasons are generated through the maximization of monthly NDVI values.

Monthly streamflow data during 1998-2009 are available for the Lijin Hydrological Station (Fig. 1), about $100 \mathrm{~km}$ upstream from the Yellow River mouth, which is provided by the Yellow River Conservancy Commission. Monthly precipitation and air temperature data for the period 1998-2009 at Dongying Meteorological Station were obtained from the National Climate Center of China (NCC), China Meteorological Administration. Land use maps of 2000 and 2009 have been interpreted based on Landsat TM images.

The slopes of the linear trends in NDVI and three variables (streamflow, precipitation, temperature) are calculated by the least squares fitting. The non-parametric Mann-Kendall test is used to test the statistical significance of all the trends at the 0.05 level. To analyse the relationships between NDVI and three variables, their Person correlation coefficients were calculated during growing season as well as on seasonal and monthly scales.

In order to better understand the regional difference of vegetation response to variations in streamflow, precipitation and temperature, five buffer zones along with the Yellow River Channel (YRC) and the Bohai Sea Coastline (BSC) are made respectively, which are identified as YRC Zone I, YRC Zone II, YRC Zone III, YRC Zone IV, YRC Zone V, and BSC Zone I, BSC Zone II, BSC Zone III, BSC Zone IV, BSC Zone V (Fig. 2).

\section{Results}

\subsection{Seasonal difference in NDVI}

NDVI shows a remarkable seasonal difference (Fig. 3, Fig. 4). Averaged over the period 1998-2009, summer has the highest NDVI value and spring has the lowest NDVI value in the whole YRD and each buffer zone (Fig. 3), mainly because, influenced by the East Asian monsoon, summer has plentiful rainfall and high temperature as well as large freshwater inflow while the opposite occurs in spring.

The monthly distribution of NDVI also indicates a similar seasonal difference. Over the YRD and all buffer zones, the maximum monthly NDVI value is observed in August (except for BSC Zone I) while the minimum is in April (Fig. 4), suggesting the effects of climate features on seasonal difference in vegetation cover.

\subsection{Interannual variation in NDVI}

From 1998 to 2009, growing season NDVI exhibits a significant increase in all YRC buffer zones (Fig. 5a), which is in accordance with a slight increase of streamflow and precipitation but is contrary to a weak decrease of temperature (Fig. 6). The decadal increases in growing season NDVI are $0.11,0.12,0.14,0.13$ and 0.07 respectively for YRC Zone I to $\mathrm{V}$ and the largest increase appears
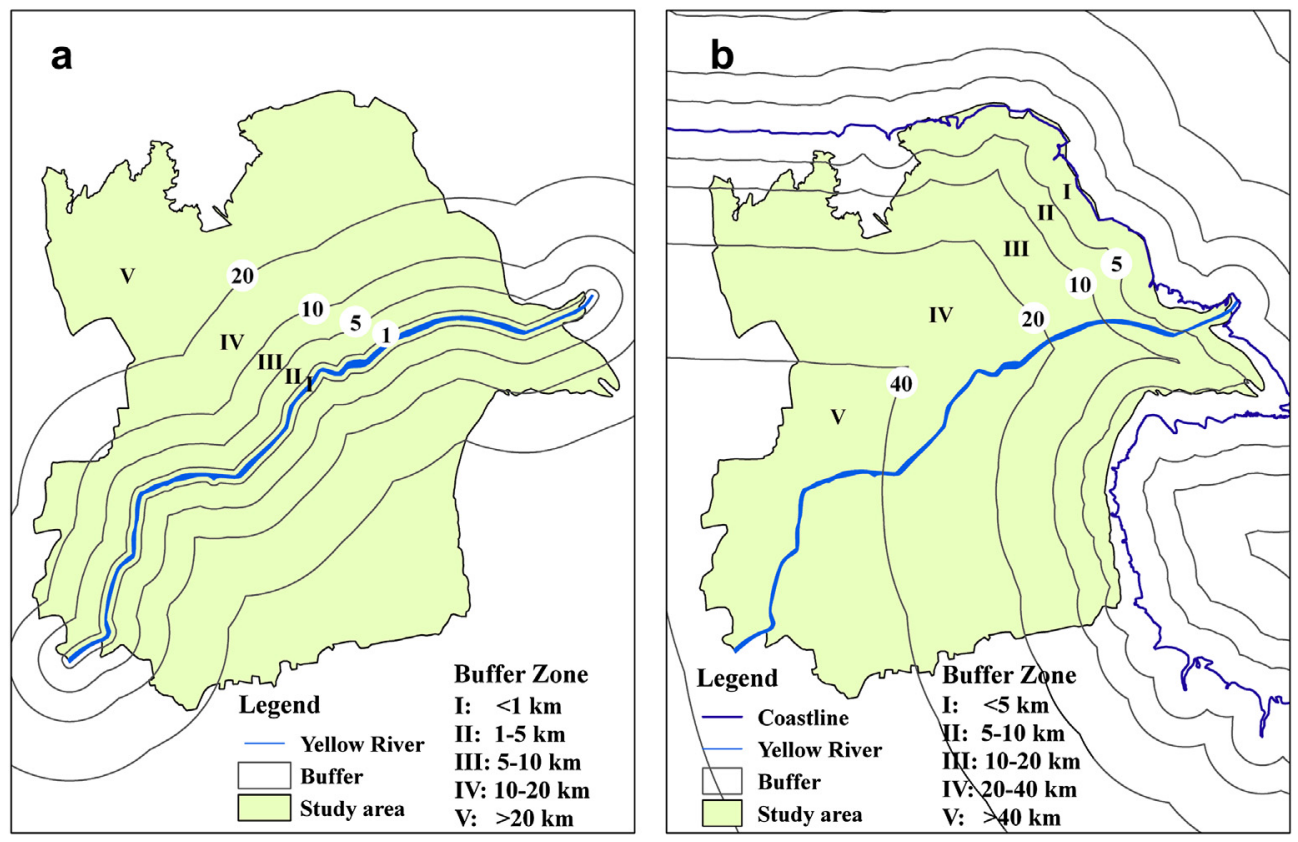

Fig. 2. Buffer zones along with the Yellow River Channel (a) and Bohai Sea Coastline (b). 
a

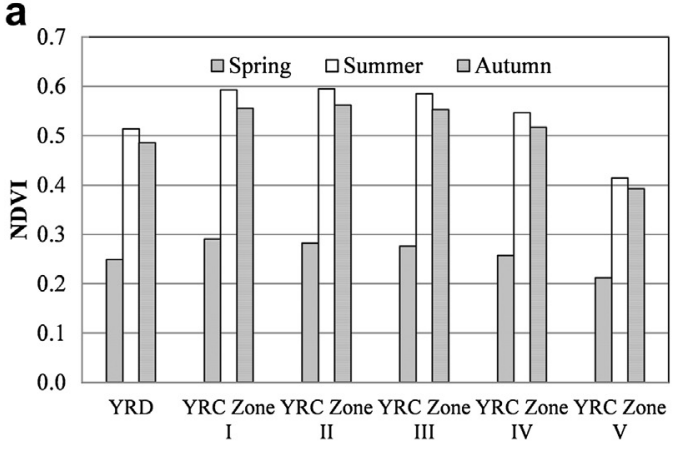

b

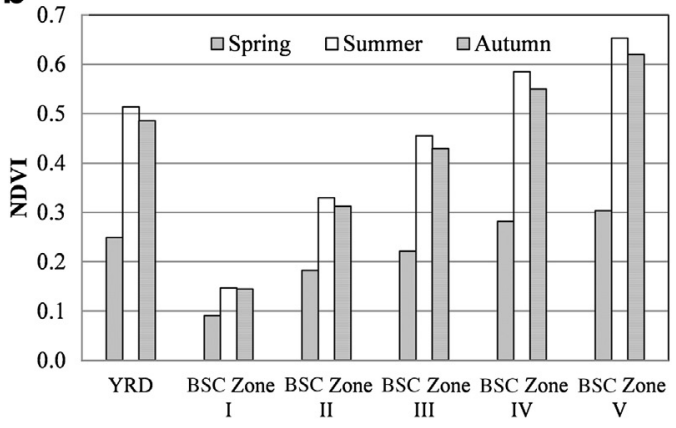

Fig. 3. Seasonal NDVI averaged for the period 1998-2009 in the buffer zones of YRC (a) and BSC (b).

in YRC Zone III. For BSC buffer zones, a dramatic increase in growing season NDVI is observed in BSC Zone III, IV and V with the decadal increments of $0.11,0.14$ and 0.13 respectively (Fig. 5b). In contrast, growing season NDVI shows a significant decrease ( $-0.03 /$ decade) in BSC Zone I (Fig. 5b). Generally, no obvious variation in growing season streamflow, precipitation and temperature but a significant increase in growing season NDVI for the past 12 years are probably attributed by that human activities affect vegetation dynamics.
Table 1 presents the Mann-Kendall test of variation in seasonal NDVI from 1998 to 2009. Spring NDVI displays a decrease in the whole study area and all buffer zones but only YRC Zone I, V and BSC Zone I, IV, V are significant at the 0.05 level. Spring streamflow and precipitation have a significant increase. In summer and autumn, NDVI shows a remarkable increase in the whole study area and all buffer zones except BSC Zone I and II. Streamflow, precipitation and temperature have no trend in these two seasons (Table 1).

Table 1

Mann-Kendall test statistic of the variation in seasonal NDVI and three variables (streamflow, precipitation, temperature) during $1998-2009$.

\begin{tabular}{|c|c|c|c|c|c|c|c|c|c|c|}
\hline & & \multicolumn{3}{|l|}{ Spring } & \multicolumn{3}{|l|}{ Summer } & \multicolumn{3}{|l|}{ Autumn } \\
\hline & & $Z$ & $\beta$ & $P$ & $Z$ & $\beta$ & $P$ & $Z$ & $\beta$ & $P$ \\
\hline \multirow[t]{11}{*}{ NDVI } & YRD & -1.851 & -0.008 & $*$ & 3.086 & 0.011 & ** & 3.360 & 0.011 & $* *$ \\
\hline & YRC I & -1.989 & -0.013 & $* *$ & 2.537 & 0.016 & $* *$ & 2.674 & 0.009 & $* *$ \\
\hline & YRC II & -1.851 & -0.011 & $*$ & 3.360 & 0.013 & $* *$ & 3.771 & 0.013 & $* *$ \\
\hline & YRC III & -1.851 & -0.010 & $*$ & 3.360 & 0.014 & $* *$ & 3.634 & 0.014 & $* *$ \\
\hline & YRC IV & -1.851 & -0.009 & $*$ & 3.223 & 0.014 & $* *$ & 3.634 & 0.013 & $* *$ \\
\hline & YRC V & -2.126 & -0.006 & $* *$ & 2.811 & 0.007 & $* *$ & 3.086 & 0.007 & $* *$ \\
\hline & BSC I & -1.989 & -0.004 & $* *$ & -1.989 & -0.004 & $* *$ & -1.440 & -0.005 & \\
\hline & BSC II & -1.029 & -0.003 & & 1.714 & 0.007 & $*$ & 1.714 & 0.005 & $*$ \\
\hline & BSC III & -1.714 & -0.007 & $*$ & 3.086 & 0.013 & $* *$ & 3.497 & 0.012 & $* *$ \\
\hline & BSC IV & -2.126 & -0.010 & $* *$ & 2.949 & 0.015 & $* *$ & 3.634 & 0.015 & $* *$ \\
\hline & BSC V & -2.126 & -0.017 & $* *$ & 2.949 & 0.014 & $* *$ & 3.497 & 0.014 & ** \\
\hline \multicolumn{2}{|c|}{ Streamflow } & 2.400 & 0.791 & $* *$ & 1.303 & 4.251 & & 1.577 & 1.963 & \\
\hline \multicolumn{2}{|c|}{ Precipitation } & 1.989 & 6.155 & $* *$ & 0.343 & 9.000 & & -0.206 & -0.638 & \\
\hline \multicolumn{2}{|c|}{ Temperature } & 1.577 & 0.077 & & -0.480 & -0.041 & & -0.206 & -0.013 & \\
\hline
\end{tabular}

Note: "*' means significant at $P<0.1$ and '**' means significant at $P<0.05$.
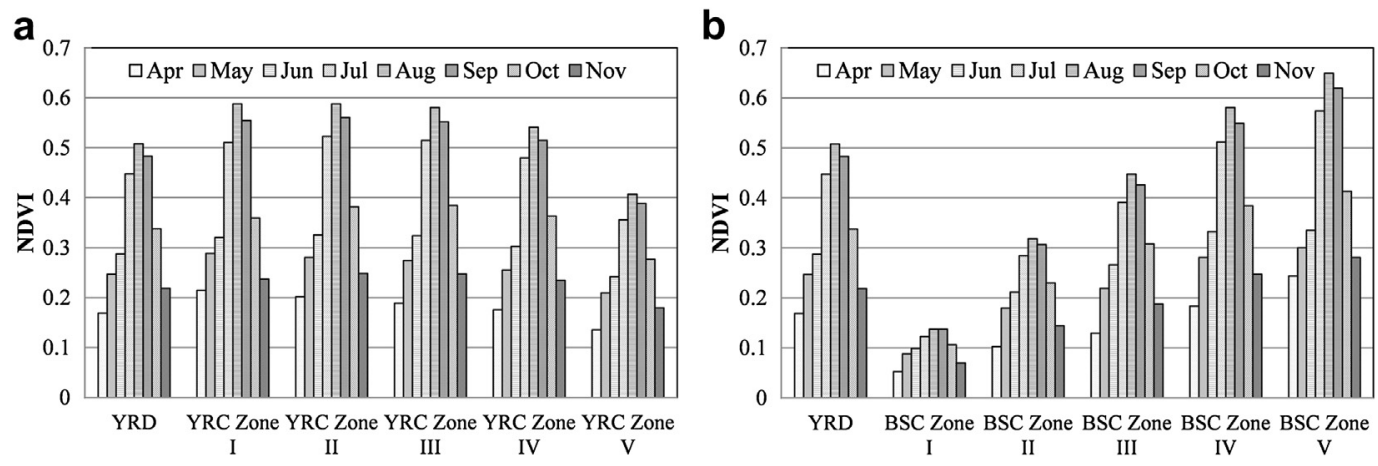

Fig. 4. Monthly NDVI averaged for the period 1998-2009 in the buffer zones of YRC (a) and BSC (b). 
The variation in monthly NDVI shows a similar pattern to that of seasonal NDVI (Table 2). A significant decrease of monthly NDVI is observed in April over the whole YRD and all buffer zones but is detected in May only in YRC Zone V and BSC Zone I, IV, which is contrary to a significant increase in April and May streamflow as well as May precipitation and temperature. In contrast, monthly NDVI exhibits a significant increase from July to October in the whole study area and all buffer zones except for BSC Zone I and II, with the highest increase appearing in July. However, streamflow, precipitation and temperature have no variation in these months.

\subsection{Regional difference in NDVI}

\subsubsection{NDVI variance along with YRC buffer zones}

Growing season NDVI decreases as the distance to the Yellow River Channel increases, with annual mean values of $0.60,0.60$, $0.59,0.55$, and 0.42 respectively for YRC Zone I to V (Fig. 5a). This result suggests that freshwater input should have impacts on the spatial distribution of vegetation cover. However, there is a slight difference among YRC Zone I, II and III, implying that plant growth may have a similar response to freshwater inflow in

Table 2

Mann-Kendall test statistic of the variation in monthly NDVI and three variables (streamflow, precipitation, temperature) during $1998-2009$.

\begin{tabular}{|c|c|c|c|c|c|c|c|c|c|c|c|c|c|c|c|}
\hline & & \multicolumn{11}{|l|}{ NDVI } & \multirow[t]{2}{*}{ Streamflow } & \multirow[t]{2}{*}{ Precipitation } & \multirow[t]{2}{*}{ Temperature } \\
\hline & & YRD & YRC I & YRC II & YRC III & YRC IV & YRC V & BSC I & BSC II & BSC III & BSC IV & BSC V & & & \\
\hline Apr & $\begin{array}{l}Z \\
\beta \\
P\end{array}$ & $\begin{array}{l}-2.674 \\
-0.011 \\
* *\end{array}$ & $\begin{array}{l}-2.263 \\
-0.016 \\
* *\end{array}$ & $\begin{array}{l}-2.263 \\
-0.015 \\
* *\end{array}$ & $\begin{array}{l}-2.263 \\
-0.012 \\
* *\end{array}$ & $\begin{array}{l}-2.674 \\
-0.011 \\
* *\end{array}$ & $\begin{array}{l}-2.811 \\
-0.009 \\
* *\end{array}$ & $\begin{array}{l}-1.989 \\
-0.004 \\
* *\end{array}$ & $\begin{array}{l}-2.400 \\
-0.004 \\
* *\end{array}$ & $\begin{array}{l}-2.537 \\
-0.007 \\
* *\end{array}$ & $\begin{array}{l}-2.811 \\
-0.013 \\
* *\end{array}$ & $\begin{array}{l}-2.263 \\
-0.017 \\
* *\end{array}$ & $\begin{array}{r}2.126 \\
10.294 \\
* *\end{array}$ & $\begin{array}{l}0.617 \\
1.338\end{array}$ & $\begin{array}{l}0.069 \\
0.004\end{array}$ \\
\hline May & $\begin{array}{l}Z \\
\beta \\
P\end{array}$ & $\begin{array}{l}-1.714 \\
-0.008 \\
*\end{array}$ & $\begin{array}{l}-1.851 \\
-0.013 \\
*\end{array}$ & $\begin{array}{l}-1.714 \\
-0.011 \\
*\end{array}$ & $\begin{array}{l}-1.714 \\
-0.010 \\
*\end{array}$ & $\begin{array}{l}-1.714 \\
-0.009 \\
*\end{array}$ & $\begin{array}{l}-2.126 \\
-0.006 \\
* *\end{array}$ & $\begin{array}{l}-1.989 \\
-0.004 \\
* *\end{array}$ & $\begin{array}{l}-0.891 \\
-0.003\end{array}$ & $\begin{array}{l}-1.851 \\
-0.007 \\
*\end{array}$ & $\begin{array}{l}-2.126 \\
-0.010 \\
* *\end{array}$ & $\begin{array}{l}-1.851 \\
-0.016\end{array}$ & $\begin{array}{r}2.674 \\
18.792 \\
* *\end{array}$ & $\begin{array}{r}2.537 \\
4.174 \\
* *\end{array}$ & $\begin{array}{r}2.263 \\
0.130 \\
* *\end{array}$ \\
\hline Jun & $\begin{array}{l}Z \\
\beta \\
P\end{array}$ & $\begin{array}{l}1.303 \\
0.006\end{array}$ & $\begin{array}{r}1.851 \\
0.010\end{array}$ & $\begin{array}{r}2.126 \\
0.010 \\
* *\end{array}$ & $\begin{array}{l}2.537 \\
0.009 \\
* *\end{array}$ & $\begin{array}{l}1.440 \\
0.004\end{array}$ & $\begin{array}{l}1.303 \\
0.002\end{array}$ & $\begin{array}{l}-1.989 \\
-0.004 \\
* *\end{array}$ & $\begin{array}{l}0.000 \\
0.000\end{array}$ & $\begin{array}{l}1.440 \\
0.003\end{array}$ & $\begin{array}{r}2.400 \\
0.006 \\
* *\end{array}$ & $\begin{array}{r}2.537 \\
0.011 \\
* *\end{array}$ & $\begin{array}{r}1.714 \\
105.478\end{array}$ & $\begin{array}{l}1.303 \\
4.783\end{array}$ & $\begin{array}{l}0.891 \\
0.084\end{array}$ \\
\hline Jul & $\begin{array}{l}Z \\
\beta \\
P\end{array}$ & $\begin{array}{r}2.674 \\
0.016 \\
* *\end{array}$ & $\begin{array}{r}2.949 \\
0.021 \\
* *\end{array}$ & $\begin{array}{r}3.086 \\
0.020 \\
* *\end{array}$ & $\begin{array}{r}2.949 \\
0.020 \\
* *\end{array}$ & $\begin{array}{r}2.949 \\
0.018 \\
* *\end{array}$ & $\begin{array}{r}2.674 \\
0.010 \\
* *\end{array}$ & $\begin{array}{l}-2.126 \\
-0.005 \\
* *\end{array}$ & $\begin{array}{r}1.851 \\
0.005\end{array}$ & $\begin{array}{r}3.223 \\
0.015 \\
* *\end{array}$ & $\begin{array}{r}2.949 \\
0.021 \\
* *\end{array}$ & $\begin{array}{r}2.674 \\
0.023 \\
* *\end{array}$ & $\begin{array}{r}1.166 \\
39.690\end{array}$ & $\begin{array}{l}0.206 \\
2.836\end{array}$ & $\begin{array}{l}-1.577 \\
-0.117\end{array}$ \\
\hline Aug & $\begin{array}{l}Z \\
\beta \\
P\end{array}$ & $\begin{array}{r}2.949 \\
0.012 \\
* *\end{array}$ & $\begin{array}{r}2.537 \\
0.015 \\
* *\end{array}$ & $\begin{array}{r}3.223 \\
0.014 \\
* *\end{array}$ & $\begin{array}{r}3.086 \\
0.015 \\
* *\end{array}$ & $\begin{array}{r}3.086 \\
0.015 \\
* *\end{array}$ & $\begin{array}{r}2.537 \\
0.008 \\
* *\end{array}$ & $\begin{array}{l}-1.029 \\
-0.003\end{array}$ & $\begin{array}{l}1.577 \\
0.007\end{array}$ & $\begin{array}{r}2.949 \\
0.014\end{array}$ & $\begin{array}{r}3.086 \\
0.016\end{array}$ & $\begin{array}{r}2.949 \\
0.012 \\
* *\end{array}$ & $\begin{array}{r}0.617 \\
22.300\end{array}$ & $\begin{array}{l}-0.617 \\
-2.886\end{array}$ & $\begin{array}{l}0.000 \\
0.005\end{array}$ \\
\hline Sep & $\begin{array}{l}Z \\
\beta \\
P\end{array}$ & $\begin{array}{r}3.497 \\
0.010\end{array}$ & $\begin{array}{r}2.674 \\
0.009 \\
* *\end{array}$ & $\begin{array}{r}3.771 \\
0.012 \\
* *\end{array}$ & $\begin{array}{r}3.634 \\
0.013 \\
* *\end{array}$ & $\begin{array}{r}3.634 \\
0.013 \\
* *\end{array}$ & $\begin{array}{r}2.674 \\
0.005 \\
* *\end{array}$ & $\begin{array}{l}-2.263 \\
-0.006 \\
* *\end{array}$ & $\begin{array}{l}1.303 \\
0.005\end{array}$ & $\begin{array}{r}3.497 \\
0.011 \\
* *\end{array}$ & $\begin{array}{r}3.634 \\
0.015\end{array}$ & $\begin{array}{r}3.497 \\
0.014\end{array}$ & $\begin{array}{r}0.754 \\
27.658\end{array}$ & $\begin{array}{l}0.617 \\
2.111\end{array}$ & $\begin{array}{l}-1.714 \\
-0.091 \\
*\end{array}$ \\
\hline Oct & $\begin{array}{l}Z \\
\beta \\
P\end{array}$ & $\begin{array}{r}3.086 \\
0.015 \\
* *\end{array}$ & $\begin{array}{r}2.949 \\
0.018 \\
* *\end{array}$ & $\begin{array}{r}2.949 \\
0.021 \\
* *\end{array}$ & $\begin{array}{r}3.086 \\
0.021 \\
* *\end{array}$ & $\begin{array}{l}2.949 \\
0.017 \\
* *\end{array}$ & $\begin{array}{r}2.400 \\
0.009 \\
* *\end{array}$ & $\begin{array}{l}-1.440 \\
-0.003\end{array}$ & $\begin{array}{l}0.891 \\
0.003\end{array}$ & $\begin{array}{r}2.400 \\
0.012 \\
* *\end{array}$ & $\begin{array}{r}3.086 \\
0.021 \\
* *\end{array}$ & $\begin{array}{r}3.223 \\
0.021 \\
* *\end{array}$ & $\begin{array}{r}1.577 \\
49.609\end{array}$ & $\begin{array}{l}-0.617 \\
-0.883\end{array}$ & $\begin{array}{l}0.754 \\
0.114\end{array}$ \\
\hline Nov & $\begin{array}{l}Z \\
\beta \\
P\end{array}$ & $\begin{array}{l}1.029 \\
0.004\end{array}$ & $\begin{array}{l}0.754 \\
0.003\end{array}$ & $\begin{array}{l}1.303 \\
0.005\end{array}$ & $\begin{array}{l}1.303 \\
0.007\end{array}$ & $\begin{array}{l}1.029 \\
0.006\end{array}$ & $\begin{array}{l}0.754 \\
0.002\end{array}$ & $\begin{array}{l}-2.263 \\
-0.005 \\
* *\end{array}$ & $\begin{array}{r}-0.275 \\
0.000\end{array}$ & $\begin{array}{l}0.754 \\
0.003\end{array}$ & $\begin{array}{l}1.440 \\
0.006\end{array}$ & $\begin{array}{l}1.303 \\
0.006\end{array}$ & $\begin{array}{r}1.512 \\
29.668\end{array}$ & $\begin{array}{l}-0.825 \\
-0.425\end{array}$ & $\begin{array}{l}-0.069 \\
-0.015\end{array}$ \\
\hline
\end{tabular}

Note: '*' means significant at $P<0.1$ and '**' means significant at $P<0.05$.

a

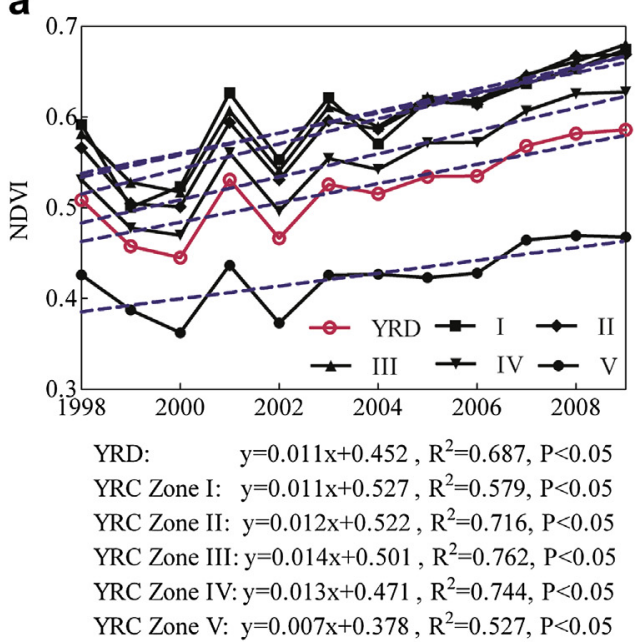

b

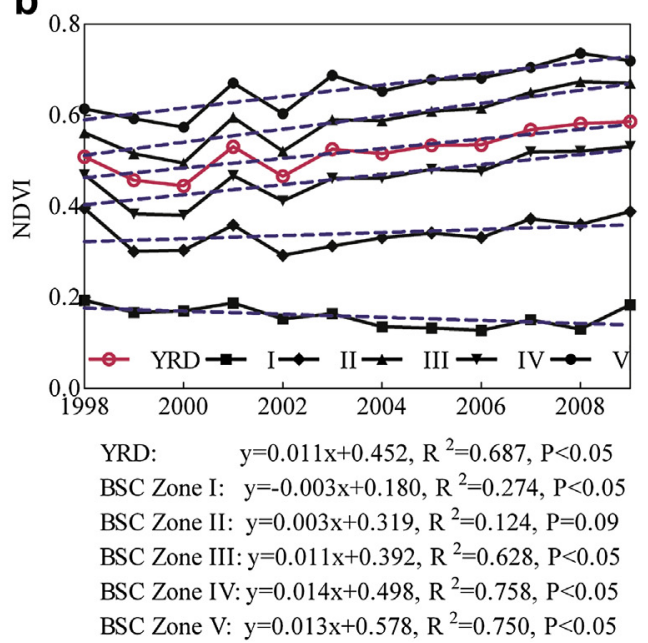

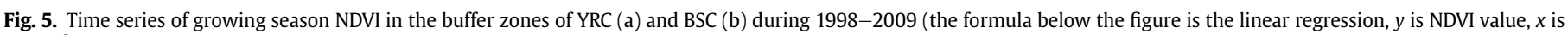
year, $R^{2}$ is the determination coefficient, $P$ is the significance level). 


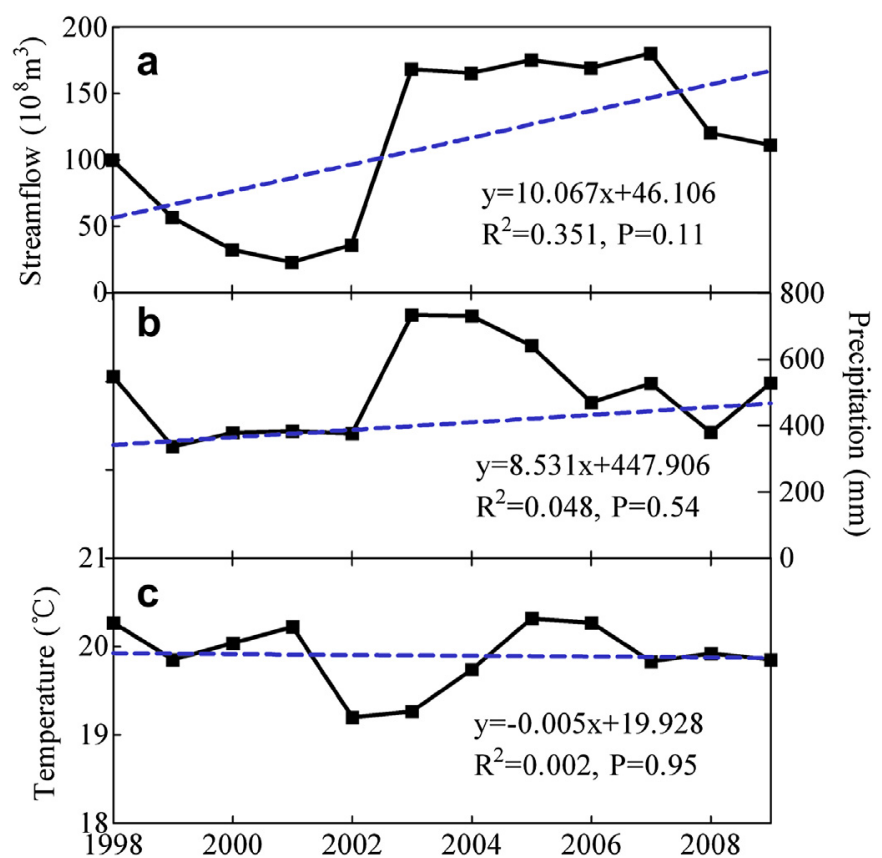

Fig. 6. Time series of growing season streamflow (a), precipitation (b) and temperature (c) during 1998-2009 (the formula below the figure is the linear regression, $y$ is the value of streamflow (a), precipitation (b) or temperature (c), $x$ is year, $R^{2}$ is the determination coefficient, $P$ is the significance level).

these zones. Seasonal and monthly NDVI also show a decrease from YRC Zone II to V (Figs. 3a and 4a), showing a similar regional difference to growing season NDVI.

\subsubsection{NDVI variance along with BSC buffer zones}

Growing season NDVI notably increases far away from the Bohai Sea coastline with annual average values of $0.16,0.34,0.46,0.59$, and 0.66 for BSC Zone I to V respectively (Fig. 5b), implying that vegetation dynamics are greatly affected by the interactions between freshwater and saltwater, and soil salinity is an important limiting factor for plant growth. The spatial distribution of seasonal and monthly NDVI is also found to have a similar pattern to that of growing season NDVI in BSC buffer zones (Figs. $3 \mathrm{~b}$ and $4 \mathrm{~b}$ ). Generally, in contrast with YRC buffer zones, the regional difference in NDVI seems to be more remarkable at BSC buffer zones (Figs. 35 ), showing that vegetation dynamics are more sensitive to the gradient of soil salinity in the YRD.

\subsection{Correlations between NDVI and streamflow as well as climate variables}

Fig. 7 displays the correlations between growing season NDVI and three variables. Growing season NDVI is strongly correlated with growing season streamflow in the whole study area and all buffer zones except YRC Zone I and V as well as BSC Zone I and II (Fig. 7a-b). In contrast, there is a weak relationship between growing season NDVI and precipitation as well as temperature (Fig. 7c-f). This finding indicates that during the entire growing season, NDVI is more closely associated with freshwater inflow than precipitation and temperature. However, a significant negative correlation between growing season NDVI and streamflow is observed in BSC Zone I with a correlation coefficient of -0.58 .

Table 3 lists the correlation coefficients between seasonal NDVI and three variables. In spring and autumn, there is no correlation between NDVI and streamflow, precipitation, temperature of both current and previous season in the whole study area and all buffer zones. Moreover, summer NDVI is also weakly linked to three variables in the current season, but is strongly associated with spring precipitation (in the whole YRD and all buffer zones except YRC Zone V and BSC Zone I-II) and temperature (in the whole YRD and all buffer zones except BSC Zone I, V), indicating that spring precipitation and temperature have a time-lag effect on plant growth.

Table 3

Correlation coefficients between seasonal NDVI and streamflow as well as climate variables (the bold value greater than 0.57 corresponds to the 0.05 significant level).

\begin{tabular}{|c|c|c|c|c|c|c|c|c|c|c|c|c|}
\hline \multirow[t]{2}{*}{ Season } & & \multirow[t]{2}{*}{ YRD } & \multicolumn{5}{|c|}{ River channel buffer zone } & \multicolumn{5}{|c|}{ Coastline buffer zone } \\
\hline & & & I & II & III & IV & V & I & II & III & IV & V \\
\hline \multirow[t]{6}{*}{ Spring } & Rs & -0.19 & -0.32 & -0.25 & -0.20 & -0.22 & -0.09 & -0.32 & 0.08 & -0.06 & -0.15 & -0.32 \\
\hline & Rs-1 & -0.12 & -0.35 & -0.25 & -0.15 & -0.13 & 0.06 & -0.05 & 0.25 & 0.14 & -0.07 & -0.35 \\
\hline & Ps & -0.55 & -0.49 & -0.53 & -0.57 & -0.56 & -0.53 & -0.38 & -0.37 & -0.45 & -0.54 & $-0.59^{*}$ \\
\hline & Ps-1 & 0.07 & 0.14 & 0.07 & 0.09 & 0.08 & 0.03 & 0.10 & 0.07 & 0.12 & 0.07 & 0.03 \\
\hline & Ts & -0.17 & -0.23 & -0.19 & -0.18 & -0.17 & -0.13 & 0.18 & 0.13 & -0.04 & -0.20 & -0.26 \\
\hline & Ts- 1 & -0.05 & -0.11 & -0.06 & -0.06 & -0.02 & -0.03 & 0.02 & -0.13 & -0.05 & -0.04 & -0.03 \\
\hline \multirow[t]{6}{*}{ Summer } & Rs & 0.47 & 0.35 & 0.46 & 0.50 & 0.47 & 0.48 & -0.57 & 0.44 & 0.54 & 0.51 & 0.39 \\
\hline & Rs-1 & 0.45 & 0.35 & 0.43 & 0.48 & 0.46 & 0.42 & $-0.65^{*}$ & 0.20 & 0.44 & 0.51 & 0.46 \\
\hline & Ps & 0.24 & 0.24 & 0.25 & 0.25 & 0.21 & 0.24 & -0.16 & 0.32 & 0.33 & 0.22 & 0.16 \\
\hline & Ps-1 & $0.64^{*}$ & $0.67^{*}$ & $0.68^{*}$ & $0.66^{*}$ & $0.64^{*}$ & 0.57 & -0.14 & 0.26 & $0.60^{*}$ & $0.64^{*}$ & $0.71^{*}$ \\
\hline & Ts & -0.39 & -0.34 & -0.38 & -0.38 & -0.36 & -0.44 & 0.26 & -0.19 & -0.41 & -0.39 & -0.42 \\
\hline & Ts-1 & $0.60^{*}$ & $0.58^{*}$ & $0.59^{*}$ & $0.59^{*}$ & $0.61^{*}$ & $0.60^{*}$ & 0.30 & $0.67^{*}$ & $0.61^{*}$ & $0.58^{*}$ & 0.53 \\
\hline \multirow[t]{6}{*}{ Autumn } & Rs & 0.25 & 0.12 & 0.25 & 0.24 & 0.24 & 0.27 & -0.20 & -0.16 & 0.26 & 0.24 & 0.31 \\
\hline & Rs-1 & 0.46 & 0.29 & 0.45 & 0.47 & 0.46 & 0.45 & $-0.61^{*}$ & 0.39 & 0.55 & 0.47 & 0.37 \\
\hline & Ps & -0.08 & -0.18 & -0.09 & -0.08 & -0.08 & -0.04 & -0.06 & -0.47 & -0.15 & -0.07 & 0.07 \\
\hline & Ps-1 & 0.18 & 0.13 & 0.16 & 0.18 & 0.16 & 0.22 & -0.12 & 0.35 & 0.33 & 0.13 & 0.08 \\
\hline & Ts & 0.14 & 0.15 & 0.11 & 0.08 & 0.09 & 0.27 & -0.15 & 0.57 & 0.24 & 0.11 & 0.03 \\
\hline & Ts-1 & -0.30 & -0.10 & -0.24 & -0.28 & -0.27 & -0.41 & 0.15 & -0.25 & -0.39 & -0.25 & -0.26 \\
\hline
\end{tabular}

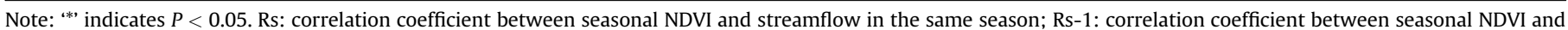

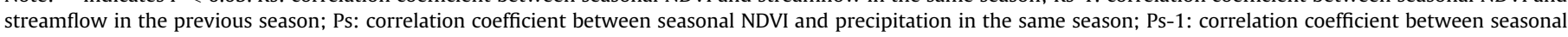

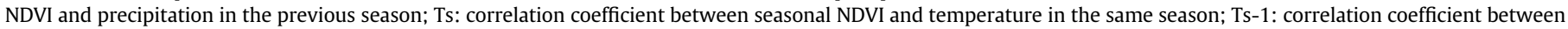
seasonal NDVI and temperature in the previous season. 


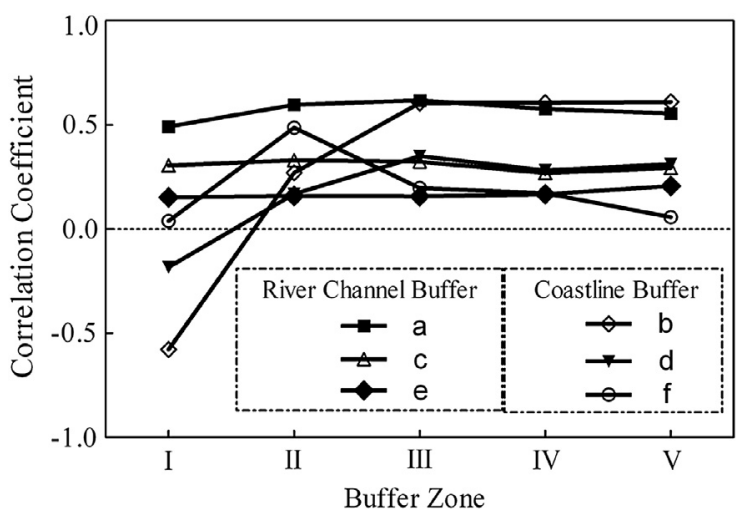

Fig. 7. Correlation coefficient between growing season NDVI and streamflow (a, b), precipitation (c, d), temperature (e, f) (the absolute value greater than 0.57 corresponds to the 0.05 significant level).
Table 4 displays the correlation coefficients between monthly NDVI and three variables. In April, May, September and October, the correlations between monthly NDVI and streamflow, precipitation, temperature of both current and previous month are all weak. In June, monthly NDVI is positively linked to streamflow (in YRC Zone I-III) and temperature (in the whole YRD and YRC Zone III, IV) of the current month but to precipitation (in the whole YRD, YRC Zone I-III and BSC Zone IV-V) of the previous month. In July, monthly NDVI is positively related to streamflow (in the whole YRD, YRC Zone III-IV and BSC Zone III-IV) of the previous month but is negatively correlated with temperature (in the whole YRD and all buffer zones except BSC Zone I-II) of the current month, which is also observed in August (for temperature in the whole YRD and all buffer zones except BSC Zone I-II). In November, monthly NDVI is negatively or positively correlated with precipitation (in the whole YRD, YRC Zone I, III, IV, and BSC Zone V) and temperature (in the whole YRD and all buffer zones except BSC Zone I-II) of the previous month respectively. It should be noted that in BSC Zone I, there is only a significant negative correlation between monthly NDVI and streamflow of the previous month from June to August.

Table 4

Correlation coefficients between monthly NDVI and streamflow as well as climate variables (the bold value greater than 0.57 corresponds to the 0.05 significant level).

\begin{tabular}{|c|c|c|c|c|c|c|c|c|c|c|c|c|}
\hline \multirow[t]{2}{*}{ Month } & & \multirow[t]{2}{*}{ YRD } & \multicolumn{5}{|c|}{ River channel buffer zone } & \multicolumn{5}{|c|}{ Coastline buffer zone } \\
\hline & & & I & II & III & IV & V & I & II & III & IV & V \\
\hline \multirow[t]{6}{*}{ Apr } & $\mathrm{Rm}$ & -0.40 & -0.44 & -0.40 & -0.39 & -0.40 & -0.39 & -0.50 & -0.27 & -0.38 & -0.40 & -0.39 \\
\hline & $\mathrm{Rm}-1$ & -0.39 & -0.46 & -0.40 & -0.38 & -0.39 & -0.36 & -0.17 & -0.16 & -0.36 & -0.40 & -0.40 \\
\hline & $\mathrm{Pm}$ & -0.48 & -0.39 & -0.46 & -0.49 & -0.49 & -0.51 & -0.55 & $-0.60^{*}$ & -0.47 & -0.48 & -0.45 \\
\hline & Pm-1 & -0.16 & -0.18 & -0.16 & -0.14 & -0.15 & -0.17 & -0.10 & -0.05 & -0.14 & -0.15 & -0.19 \\
\hline & $\mathrm{Tm}$ & 0.24 & 0.19 & 0.19 & 0.22 & 0.25 & 0.28 & 0.16 & 0.38 & 0.39 & 0.27 & 0.12 \\
\hline & Tm-1 & 0.18 & 0.13 & 0.16 & 0.19 & 0.20 & 0.18 & 0.02 & 0.03 & 0.15 & 0.20 & 0.19 \\
\hline \multirow[t]{6}{*}{ May } & $\mathrm{Rm}$ & -0.21 & -0.35 & -0.27 & -0.22 & -0.23 & -0.10 & -0.33 & 0.06 & -0.08 & -0.17 & -0.33 \\
\hline & $\mathrm{Rm}-1$ & -0.07 & -0.19 & -0.11 & -0.07 & -0.09 & 0.02 & -0.23 & 0.18 & 0.02 & -0.04 & -0.16 \\
\hline & $\mathrm{Pm}$ & -0.37 & -0.37 & -0.34 & -0.38 & -0.39 & -0.35 & -0.10 & -0.06 & -0.30 & -0.38 & -0.43 \\
\hline & Pm-1 & -0.44 & -0.35 & -0.44 & -0.46 & -0.44 & -0.44 & -0.46 & -0.48 & -0.38 & -0.42 & -0.44 \\
\hline & $\mathrm{Tm}$ & -0.22 & -0.27 & -0.24 & -0.22 & -0.22 & -0.19 & 0.07 & -0.07 & -0.19 & -0.25 & -0.24 \\
\hline & Tm-1 & 0.09 & 0.09 & 0.09 & 0.08 & 0.10 & 0.10 & 0.11 & 0.27 & 0.20 & 0.09 & 0.00 \\
\hline \multirow[t]{6}{*}{ Jun } & $\mathrm{Rm}$ & 0.52 & $0.62^{*}$ & 0.59* & $0.59^{*}$ & 0.44 & 0.42 & -0.50 & 0.25 & 0.52 & 0.56 & 0.57 \\
\hline & Rm-1 & 0.21 & 0.30 & 0.29 & 0.27 & 0.12 & 0.12 & $-0.63^{*}$ & -0.13 & 0.13 & 0.27 & 0.30 \\
\hline & $\mathrm{Pm}$ & 0.27 & 0.35 & 0.31 & 0.27 & 0.24 & 0.23 & -0.14 & 0.10 & 0.40 & 0.31 & 0.22 \\
\hline & Pm-1 & $0.65^{*}$ & $0.75^{*}$ & $0.73^{*}$ & $0.66^{*}$ & 0.57 & 0.57 & -0.03 & 0.26 & 0.55 & 0.69* & $0.68^{*}$ \\
\hline & $\mathrm{Tm}$ & $0.58^{*}$ & 0.44 & 0.54 & 0.59* & $0.64^{*}$ & 0.56 & 0.43 & 0.48 & 0.57 & 0.56 & 0.54 \\
\hline & Tm-1 & 0.35 & 0.21 & 0.29 & 0.35 & 0.41 & 0.36 & -0.01 & 0.04 & 0.20 & 0.37 & 0.41 \\
\hline \multirow[t]{6}{*}{ Jul } & $\mathrm{Rm}$ & 0.49 & 0.39 & 0.43 & 0.47 & 0.48 & $0.58^{*}$ & -0.38 & 0.57 & $0.60^{*}$ & 0.49 & 0.40 \\
\hline & $\mathrm{Rm}-1$ & $0.58^{*}$ & 0.53 & 0.57 & $0.60^{*}$ & $0.59^{*}$ & 0.57 & $-0.68^{*}$ & 0.46 & $0.61^{*}$ & $0.60^{*}$ & 0.56 \\
\hline & $\mathrm{Pm}$ & 0.51 & 0.51 & 0.51 & 0.49 & 0.48 & 0.53 & 0.01 & 0.53 & 0.55 & 0.48 & 0.46 \\
\hline & Pm-1 & 0.44 & 0.41 & 0.40 & 0.40 & 0.40 & 0.53 & 0.12 & 0.44 & 0.49 & 0.40 & 0.39 \\
\hline & $\mathrm{Tm}$ & $-0.69^{*}$ & $-0.66^{*}$ & $-0.67^{*}$ & $-0.66^{*}$ & $-0.68^{*}$ & $-0.74^{*}$ & 0.44 & -0.23 & $-0.62^{*}$ & $-0.72^{*}$ & $-0.72^{*}$ \\
\hline & Tm-1 & 0.05 & 0.10 & 0.09 & 0.07 & 0.08 & -0.05 & 0.18 & 0.19 & 0.05 & 0.02 & 0.05 \\
\hline \multirow[t]{6}{*}{ Aug } & $\mathrm{Rm}$ & 0.25 & 0.13 & 0.20 & 0.25 & 0.24 & 0.31 & -0.26 & 0.38 & 0.34 & 0.28 & 0.13 \\
\hline & $\mathrm{Rm}-1$ & 0.34 & 0.15 & 0.31 & 0.38 & 0.36 & 0.32 & $-0.60^{*}$ & 0.21 & 0.39 & 0.41 & 0.26 \\
\hline & $\mathrm{Pm}$ & -0.03 & -0.04 & -0.05 & -0.02 & -0.03 & -0.02 & -0.22 & 0.17 & 0.05 & -0.01 & -0.12 \\
\hline & Pm-1 & 0.27 & 0.32 & 0.29 & 0.31 & 0.25 & 0.25 & -0.01 & 0.28 & 0.35 & 0.25 & 0.23 \\
\hline & $\mathrm{Tm}$ & -0.35 & -0.22 & -0.35 & -0.35 & -0.31 & -0.39 & 0.16 & -0.22 & -0.37 & -0.35 & -0.34 \\
\hline & Tm-1 & $-0.68^{*}$ & $-0.63^{*}$ & $-0.69^{*}$ & $-0.68 *$ & $-0.65^{*}$ & $-0.69^{*}$ & 0.09 & -0.40 & $-0.67^{*}$ & $-0.67^{*}$ & $-0.72^{*}$ \\
\hline \multirow[t]{6}{*}{ Sep } & $\mathrm{Rm}$ & 0.32 & 0.14 & 0.30 & 0.31 & 0.30 & 0.40 & -0.16 & 0.01 & 0.35 & 0.30 & 0.34 \\
\hline & $\mathrm{Rm}-1$ & 0.15 & 0.07 & 0.14 & 0.15 & 0.14 & 0.18 & -0.36 & 0.38 & 0.30 & 0.14 & 0.03 \\
\hline & $\mathrm{Pm}$ & 0.13 & 0.03 & 0.12 & 0.12 & 0.12 & 0.15 & -0.35 & -0.36 & 0.09 & 0.14 & 0.26 \\
\hline & Pm-1 & -0.12 & -0.06 & -0.11 & -0.13 & -0.13 & -0.10 & -0.16 & 0.34 & 0.05 & -0.15 & -0.23 \\
\hline & $\mathrm{Tm}$ & -0.47 & -0.46 & -0.52 & -0.51 & -0.50 & -0.32 & 0.30 & 0.43 & -0.31 & -0.53 & $-0.61^{*}$ \\
\hline & $\mathrm{Tm}-1$ & -0.18 & -0.03 & -0.15 & -0.17 & -0.15 & -0.24 & 0.25 & -0.05 & -0.24 & -0.17 & -0.16 \\
\hline \multirow[t]{6}{*}{ Oct } & $\mathrm{Rm}$ & 0.21 & 0.26 & 0.25 & 0.23 & 0.22 & 0.11 & -0.21 & -0.19 & 0.12 & 0.16 & 0.36 \\
\hline & Rm-1 & 0.16 & 0.20 & 0.20 & 0.19 & 0.16 & 0.09 & -0.26 & -0.13 & 0.07 & 0.13 & 0.29 \\
\hline & $\mathrm{Pm}$ & -0.34 & -0.33 & -0.33 & -0.32 & -0.34 & -0.37 & 0.13 & -0.41 & -0.39 & -0.36 & -0.26 \\
\hline & Pm-1 & 0.28 & 0.32 & 0.31 & 0.29 & 0.28 & 0.22 & -0.27 & -0.14 & 0.18 & 0.23 & 0.44 \\
\hline & $\mathrm{Tm}$ & 0.20 & 0.15 & 0.19 & 0.19 & 0.19 & 0.23 & -0.08 & 0.28 & 0.20 & 0.22 & 0.15 \\
\hline & Tm-1 & -0.44 & -0.49 & -0.51 & -0.50 & -0.43 & -0.31 & 0.19 & 0.16 & -0.35 & -0.47 & -0.49 \\
\hline
\end{tabular}


Table 4 (continued)

\begin{tabular}{|c|c|c|c|c|c|c|c|c|c|c|c|c|}
\hline \multirow[t]{2}{*}{ Month } & & \multirow[t]{2}{*}{ YRD } & \multicolumn{5}{|c|}{ River channel buffer zone } & \multicolumn{5}{|c|}{ Coastline buffer zone } \\
\hline & & & $\mathrm{I}$ & II & III & IV & V & I & II & III & IV & V \\
\hline \multirow[t]{6}{*}{ Nov } & $\mathrm{Rm}$ & -0.36 & -0.39 & -0.30 & -0.29 & -0.33 & -0.46 & -0.44 & -0.50 & -0.36 & -0.30 & -0.30 \\
\hline & $\mathrm{Rm}-1$ & -0.33 & -0.31 & -0.26 & -0.26 & -0.30 & -0.43 & -0.41 & -0.44 & -0.33 & -0.29 & -0.26 \\
\hline & $\mathrm{Pm}$ & -0.44 & -0.45 & -0.37 & -0.43 & -0.46 & -0.44 & 0.10 & -0.45 & -0.55 & -0.44 & -0.36 \\
\hline & Pm-1 & $-0.59^{*}$ & $-0.68^{*}$ & -0.57 & $-0.58^{*}$ & $-0.58^{*}$ & -0.55 & -0.09 & -0.45 & -0.54 & -0.53 & $-0.63^{*}$ \\
\hline & $\mathrm{Tm}$ & 0.21 & 0.32 & 0.19 & 0.18 & 0.17 & 0.26 & -0.29 & 0.41 & 0.29 & 0.14 & 0.24 \\
\hline & Tm-1 & $0.81^{*}$ & $0.76^{*}$ & $0.84^{*}$ & $0.82^{*}$ & $0.82^{*}$ & $0.72^{*}$ & 0.12 & 0.46 & $0.65^{*}$ & $0.78^{*}$ & 0.89* \\
\hline
\end{tabular}

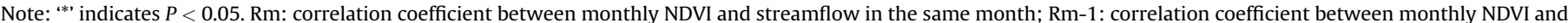

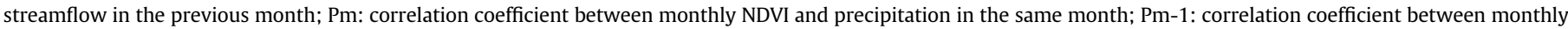

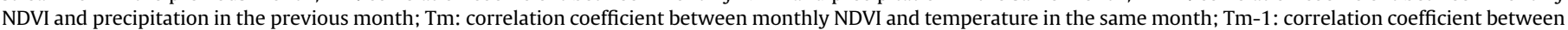
monthly NDVI and temperature in the previous month.

\section{Discussion}

\subsection{Response of NDVI to climate variables}

During growing season, an increase in NDVI but no variation in precipitation and temperature show that vegetation dynamics seem to have no obvious response to precipitation and temperature. Seasonally, the highest NDVI value in summer (August) and the lowest in spring (April) are accordant to the seasonal difference in climate. In spring, low precipitation and temperature as well as freshwater inflow make vegetation grow slowly. In contrast, these three variables are relatively high in summer, and thus, vegetation grows fast and NDVI can reach the maximum value. However, there is no correlation between NDVI and precipitation, temperature in the current season and only summer NDVI is significantly correlated with precipitation and temperature of the previous season, indicating that vegetation response to climate variables may be affected by other factors.

On a monthly scale, June NDVI has a positive correlation with temperature of the current month as well as precipitation of the previous month, because the increase of May precipitation can effectively enhance soil moisture and promote plant growth in the next month under the conditions of suitable air temperature. However, excessive temperature in July may cause much water vapour to be evaporated and subsequently restrain plant growth in the current and next month, and hence, NDVI in July and August shows a negative correlation with July temperature. In late autumn, high temperature can prevent vegetation from freezing and withering but plentiful rainfall may be unfavourable for plant growth under low temperature. Thus, November NDVI has a positive correlation with October temperature but a negative relationship with October precipitation. However, other months have no correlation between monthly NDVI and climate variables of current and previous months. It seems that these findings are inconsistent with the results of Li et al. (2007) and Li et al. (2011), who reported that monthly NDVI is closely correlated with monthly precipitation, temperature and NDVI notably lags behind precipitation by one month. Li et al. (2007) and Li et al. (2011) used a pair of all monthly data for the study period to calculate the correlation coefficient between NDVI and climate variables.

\subsection{Unique response of NDVI to freshwater inflow and soil salinity}

In the YRD, plant growth and vegetation landscape are deeply influenced by the interactions between freshwater and saltwater. NDVI values show a notable increase with the decrease of the distance to the Yellow River Channel and the increment of the distance to the Bohai Sea. Many studies have noted that on a local scale of the YRD, the gradient of water depth and soil salinity largely determines plant communities and the spatial distribution pattern of vegetation is consistent with that of soil salinity (Tan and Zhao, 2006; Song et al., 2008; Wu et al., 2009; Cui et al., 2009b, 2010; Jiang et al., 2011).

Freshwater inflow has a great effect on water-salt regimes and thus, on plant communities and vegetation dynamics ( $\mathrm{Li}$ et al., 2009; Wu et al., 2009; Cui et al., 2009b; Wang et al., 2011). During the entire growing season, there is a close correlation between NDVI and streamflow in the YRD. Water consumption by agriculture, industry and domestic sectors as well as ecosystem (especially estuary wetland) in the YRD mainly depends on the incoming water of the Yellow River. A number of plain reservoirs, which water is diverted from the Yellow River, have been constructed to provide water for human being, especially for farmland irrigation. Hence, upstream inflow is essential for the YRD. However, in BSC Zone I, growing season NDVI and streamflow have a negative correlation, primarily because vegetation is strongly influenced by coastal erosion, exploitation and utilization of coastal beaches as well as sediment deposition in the Yellow River estuary. Moreover, the increase of freshwater inflow may submerge vegetation or transport more sediment depositing in this buffer zone.

On a monthly scale, NDVI in June and July has a positive correlation with June streamflow, probably because the implementation of water and sedimentation regulation in the Yellow River has mostly started from the second ten days of June to the early July. In this period, high water flow has been discharged from Wanjiazhai, Sanmenxia and Xiaolangdi reservoirs to the downstream in order to transport sediment into the Bohai Sea, to increase the flowing capacity of the lower reaches of the Yellow River Channel and to improve the ecological status of the Yellow River estuary wetland, which can greatly enhance plant growth and increase NDVI values.

\subsection{Impacts of human activities on NDVI variation}

NDVI shows different strengths of correlation with freshwater inflow or climate variables and their correlations varies in different seasons and months. However, the relationships between NDVI and three variables are not close in many cases. For example, NDVI is not linked to climate variables during the entire growing season, NDVI has no correlation with streamflow in three seasons, and there is no relation between NDVI and three variables in April, September and October. Therefore, other factors, such as human activities, especially land use pattern and land use change as well as water diversion from the Yellow River, may become more relevant, overriding the potential effect of freshwater inflow, precipitation and temperature.

In the YRD, farmland is the primary land use type (Table 5), accounting for about $50 \%$ of the total study area. And from 2000 to 2009 , farmland increases by $6.88 \%$, which is converted mostly from grassland and salina (Fig. 8). With good irrigation management, the 

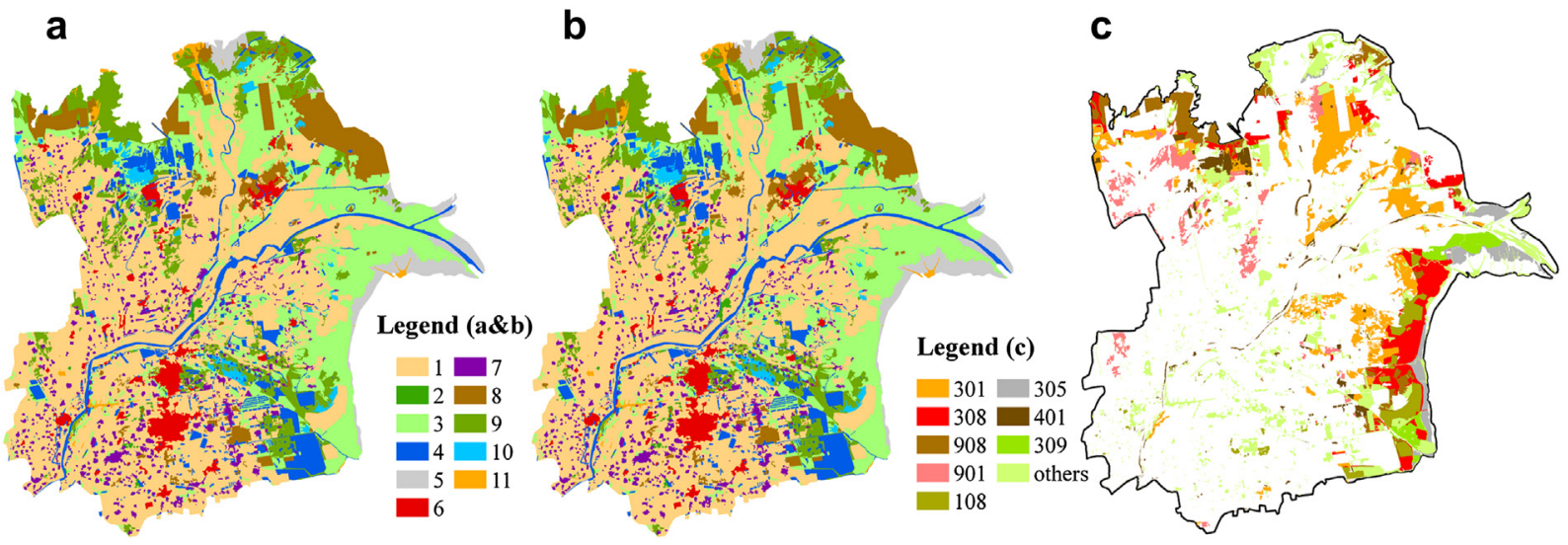

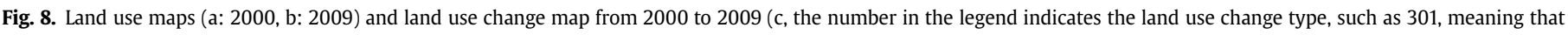
grassland in 2000 changed to farmland in 2009).

expansion of farmland can increase the maximum value of growing season NDVI. Seasonally, crops are mainly in the germination and growth period in spring, in exuberance period in summer and in harvest period in autumn. Hence, agricultural development can decrease spring NDVI and increase summer and autumn NDVI. Li and Xu (2008) and Fang et al. (2005) also reported that NDVI distribution agrees well with land use pattern and human activities especially agricultural cultivation have dramatic influences on seasonal variation of NDVI in the YRD. However, the conversions from grassland to oilfield and road, beach, salina and from salina to oilfield and road are the main land use change in BSC Zone I from 2000 to 2009, which largely contribute to a decrease in NDVI in this zone.

Table 5

Land use area of 2000 and 2009 in the study area.

\begin{tabular}{llrrr}
\hline No & Name & Area $\left(\mathrm{km}^{2}\right)$ & & $\begin{array}{l}\text { Area change } \\
(2000-2009) \\
\text { of the total } \\
\text { area (\%) }\end{array}$ \\
\cline { 3 - 5 } & & 2000 & 2009 & 6.88 \\
\hline 1 & & 2745.01 & 3165.16 & -0.05 \\
2 & Farmland & 16.04 & 13.28 & -12.50 \\
3 & Forest & 1159.93 & 396.23 & -1.14 \\
4 & Water & 474.30 & 404.75 & 1.88 \\
5 & Beach & 175.98 & 290.65 & 0.95 \\
6 & City & 179.07 & 237.11 & 0.36 \\
7 & Rural settlements & 273.51 & 295.29 & 8.48 \\
8 & Oilfield and road & 398.24 & 916.17 & -4.11 \\
9 & Salina & 570.27 & 319.43 & -0.28 \\
10 & Wetland & 70.99 & 54.03 & -0.40 \\
11 & Unused land & 46.36 & 21.83 & \\
\hline
\end{tabular}

Additionally, human activities affect freshwater input scenarios and subsequently vegetation dynamics of the YRD. For example, the incoming water supply to the YRD and its seasonal variation has been modified by a range of human activities, including river regulation, river diversion, and excessive water abstraction of surface and groundwater supplies (Cui et al., 2009a). Especially in the estuarine wetland, the ecosystem and its functions have been degraded. Therefore, it is necessary to develop an effective management system to reduce the disturbances of human activities, save the rare and endangered species, protect the relative rarity of the wetlands, and restore the water landscape for recreation (Cui et al., 2009a, 2009b; Wang et al., 2011).

\section{Conclusions}

Based on SPOT Vegetation NDVI data, streamflow data and meteorological data for the period 1998-2009, NDVI variation and its response to freshwater inflow and climate variables in the Yellow River Delta at different temporal scales have been examined. The results show that NDVI has a remarkable seasonal and regional difference. The maximum NDVI value is observed in summer (August) while the minimum is in spring (April). Under the joint influence of freshwater inflow and soil salinity, NDVI values notably decrease as the distance to the Yellow River Channel increases and the distance to the Bohai Sea Coastline decreases. From 1998 to 2009, growing season NDVI shows a significant increase in the whole study area and all buffer zones except for BSC Zone I and II. Summer and autumn NDVI have a similar trend pattern to growing season NDVI but spring NDVI displays a significant decrease in YRC Zone I, V and BSC Zone I, IV, V. The variation in monthly NDVI is accordant with that of seasonal NDVI.

During 1998-2009, NDVI exhibits different strengths of correlation with freshwater inflow, precipitation and temperature respectively and their correlations vary in different seasons and months. During growing seasons, NDVI is closely associated with streamflow but is weakly linked to climate variables. Seasonally, there is a correlation between summer NDVI and climate variables of the previous season. On a monthly scale, NDVI is correlated positively with streamflow and temperature in June but is negatively with temperature in July. Moreover, monthly NDVI also shows a response to three variables with time lag of one month. In summary, freshwater inflow is a key factor for vegetation dynamics and for the maintenance and restoration of estuarine wetland ecosystem. Climate features play a dominant role in seasonal variation in vegetation cover. However, vegetation response to freshwater inflow and climate variables have been strongly influenced by a range of human activities such as land use pattern and land use change as well as water diversion from the Yellow River. Thus, it is anticipated to adjust land use structure and to convert farmlands, mainly in embanked former back swamps and abandoned river courses, into grassland in order to protect the newborn wetland and restore the degraded wetland of the YRD (Fang et al., 2005). In addition, the scheme about water and sedimentation regulation in the Yellow River is expected to be optimized to ensure sufficient freshwater flowing into the Bohai Sea not only in summer but also in other seasons, particularly in spring when plant growth has high water demand due to little rainfall. Generally, the work of this study will be helpful for decision-making regarding regional ecological protection and economic development. 


\section{Acknowledgements}

This study is supported by the National Natural Science Foundation of China (No. 40901028). The authors kindly thank the Yellow River Conservancy Commission, the National Climate Center (NCC) of the China Meteorological Administration and the Flemish Institute for Technological Research (VITO) for providing the data for this study.

\section{References}

An, L.S., Zhao, Q.S., Ye, S.Y., Lin, G.Q., Ding, X.G., 2011. Water-salt interactions factors and vegetation effects in the groundwater ecosystem in Yellow River Delta. Advances in Water Science 22 (5), 689-695 (in Chinese).

Cui, B.S., Tang, N., Zhao, X.S., Bai, J.H., 2009a. A management-oriented valuation method to determine ecological water requirement for wetlands in the Yellow River Delta of China. Journal for Nature Conservation 17, 129-141.

Cui, B.S., Yang, Q.C., Yang, Z.F., Zhang, K.J., 2009b. Evaluating the ecological performance of wetland restoration in the Yellow River Delta, China. Ecological Engineering 35, 1090-1103.

Cui, B.S., Yang, Q.C., Zhang, K.J., Zhao, X.S., You, Z.Y., 2010. Responses of saltcedar (Tamarix chinensis) to water table depth and soil salinity in the Yellow River Delta, China. Plant Ecology 209, 279-290.

Fabricante, I., Oesterheld, M., Paruelo, J.M., 2009. Annual and seasonal variation of NDVI explained by current and previous precipitation across Northern Patagonia. Journal of Arid Environments 73, 745-753.

Fang, H.L., Liu, G.H., Kearney, M., 2005. Georelational analysis of soil type, soil salt content, landform, and land use in the Yellow River Delta, China. Environment Management 35, 72-83.

Holben, B.N., 1986. Characteristics of maximum value composite images from temporal AVHRR data. International Journal of Remote Sensing 7, 1417-1434.

Hyfield, E.C.G., Day, J.W., Cable, J.E., Justic, D., 2008. The impacts of re-introducing Mississippi River water on the hydrologic budget and nutrient inputs of a deltaic estuary. Ecological Engineering 32, 347-359.

Jiang, R.Z., Li, X.Q., Zhu, Y.A., Zhang, Z.G., 2011. Spatial-temporal variation of NPP and NDVI correlation in wetland of Yellow River Delta based on MODIS data Acta Ecologica Sinica 22 (1), 6708-6716 (in Chinese).

Li, F.P., Xu, Z.X., 2008. Temporal and spatial distribution law of NDVI and albedo of the Yellow River delta. Yellow River 30 (2), 3-5. 8. (in Chinese).

Li, M.J., Hou, X.Y., Ying, L.L., Lu, X., Zhu, M.M., 2011. The spatial-temporal change of NDVI and its' response characteristic to temperature and precipitation in Yellow River Delta, from 1998 to 2008. Resource Science 33 (2), 322-327 (in Chinese).

Li, S.N., Wang, G.X., Deng, W., Hu, Y.M., Hua, W.W., 2009. Influence of hydrology process on wetland landscape pattern: a case study in the Yellow River Delta. Ecological Engineering 35, 1719-1726.

Li, X.T., Huang, S.F., Li, J.R., Xu, M., Yang, H.B., Sun, T., 2007. NDVI variation and climatic factor of the Yellow River delta in recent years. Yellow River 30 (2), 1112 (in Chinese).

Meng, M., Ni, J., Zong, M.J., 2011. Impacts of changes in climate variability on regional vegetation in China: NDVI-based analysis from 1982 to 2000. Ecological Research 26, 421-428.

Nemani, R.R., Keeling, C.D., Hashimoto, H., 2003. Climate-driven increases in global terrestrial net primary production from 1982 to 1999 . Science 300, 1560-1563.
Notaro, M., 2008. Response of the mean global vegetation distribution to interannual climate variability. Climate Dynamics 30, 845-854.

Piao, S.L., Fang, J.Y., Ji, W., Guo, Q.H., Ke, J.H., Tao, S., 2004. Variation in a satellitebased vegetation index in relation to climate in China. Journal of Vegetation Science 15, 219-226.

Piao, S.L., Mohammat, A., Fang, J.Y., Cai, Q., Feng, J.M., 2006. NDVI-based increase in growth of temperate grasslands and its responses to climate changes in China. Global Environmental Change 16, 340-348.

Potter, C., Boriah, S., Steinbach, M., Kumar, V., Klooster, S., 2008. Terrestrial vegetation dynamics and global climate controls. Climate Dynamics 31, 67-78.

Rees, M., Condit, R., Crawley, M., Pacala, S., Tilman, D., 2001. Long-term studies of vegetation dynamics. Science 293, 650-655.

Roerink, G.J., Menenti, M., Soepboer, W., Su, Z., 2003. Assessment of climate impact on vegetation dynamics by using remote sensing. Physics and Chemistry of the Earth 28, 103-109.

Salim, H.A., Chen, X.L., Gong, J.Y., 2008. Analysis of sudan vegetation dynamics using NOAA-AVHRR NDVI data from 1982-1993. Journal of Asian Earth Sciences $1,1-15$.

Song, C.Y., Liu, G.Y., Liu, Q.S., Cao, M.C., Huang, C., 2008. Distribution patterns of plant communities in the Yellow River Delta and related affecting factors. Chinese Journal of Ecology 27, 2042-2048 (in Chinese).

Sun, T., Yang, Z.F., Cui, B.S., 2008. Critical environmental flows to support integrated ecological objectives for the Yellow River Estuary, China. Water Resources Management 22 (8), 973-989.

Sun, T., Xu, J., Yang, Z.F., 2012. Objective-based method for environmental flow assessment in estuaries and its application to the Yellow River Estuary, China. Estuaries and Coasts 35, 892-903.

Tan, X., Zhao, X., 2006. Spatial distribution and ecological adaptability of wetland vegetation in Yellow River Delta along a water table depth gradient. Chinese Journal of Ecology 25, 1460-1464 (in Chinese).

Wang, X.G., Lian, Y., Huang, C., Wang, X.J., Wang, R.L., Shan, K., Pedroli, B. Eupen, M.V., ElMahdi, A., Ali, M., 2011. Environmental flows and its evaluation of restoration effect based on LEDESS model in Yellow River Delta wetlands. Mitigation and Adaptation Strategies for Global Change. http://dx.doi.org/ 10.1007/s11027-011-9330-x.

Wu, D.Q., Liu, J., Wang, W., Ding, W.J., Wang, R.Q., 2009. Multiscale analysis of vegetation index and topographic variables in the Yellow River Delta. Chinese Journal of Plant Ecology 33 (2), 237-245 (in Chinese).

Xie, T., Liu, X.H., Sun, T., 2010. The effects of groundwater table and flood irrigation strategies on soil water and salt dynamics and reed water use in the Yellow River Delta, China. Ecological Modelling. http://dx.doi.org/10.1016/ j.ecolmodel.2010.01.012.

Xu, X.G., Guo, H.H., Chen, X.L., Lin, H.P., Du, Q.L., 2002. A multi-scale study on land use and land cover quality change: the case of the Yellow River Delta in China. Geo Journal 3, 177-183.

Xu, Y.J., Wu, K.S., 2006. Seasonality and interannual variability of freshwater inflow to a large oligohaline estuary in the Northern Gulf of Mexico. Estuarine, Coastal and Shelf Science 68, 619-626.

Yu, L., Cao, M.K., Li, K.R., 2006. Climate-induced changes in the vegetation pattern of China in the 21st century. Ecological Research 21, 912-919.

Zhang, T.T., Zeng, S.L., Gao, Y., Ouyang, Z.T., Li, B., Fang, C.M., Zhao, B., 2011. Assessing impact of land uses on land salinization in the Yellow River Delta, China using an integrated and spatial statistical model. Land Use Policy 28, 857-866.

Zhong, L., Ma, Y.M., Salama, S.M., Su, Z.B., 2010. Assessment of vegetation dynamics and their response to variations in precipitation and temperature in the Tibetan Plateau. Climatic Change 103, 519-535. 